\title{
Expression of inhibin $\alpha$ in adrenocortical tumours reflects the hormonal status of the neoplasm
}

\author{
J Arola ${ }^{1}$, J Liu ${ }^{1}$, P Heikkilä ${ }^{1}$, V Ilvesmäki ${ }^{2}$, K Salmenkivi ${ }^{1}$, \\ R Voutilainen ${ }^{3}$ and A I Kahri ${ }^{1}$ \\ ${ }^{1}$ Department of Pathology, Haartman Institute, University of Helsinki and Helsinki University Central Hospital, Helsinki, Finland \\ ${ }^{2}$ Department of Medicine, Helsinki University Central Hospital, Helsinki, Finland \\ ${ }^{3}$ Department of Paediatrics, Kuopio University Hospital, Kuopio, Finland \\ (Requests for offprints should be addressed to J Arola, Haartman Institute, Department of Pathology, PO Box 21, FIN-00014 University of Helsinki, Finland; \\ Email: johanna.t.arola@helsinki.fi)
}

\begin{abstract}
Inhibins are gonadal glycoprotein hormones whose main endocrine function is to inhibit pituitary FSH secretion. In addition to testes and ovaries, other steroid-producing organs are sites of inhibin $\alpha$ subunit expression. To study the role of inhibins in human adrenal gland, we screened a panel of 150 adrenals (10 normal adrenals, 25 adrenocortical hyperplasias, 65 adrenocortical adenomas, 30 adrenocortical carcinomas and 20 phaeochromocytomas) for inhibin $\alpha$ expression. mRNA levels of inhibin $\alpha$ subunit were studied in 57 samples and all tissues were stained immunohistochemically with an inhibin $\alpha$ subunit-specific antibody. Inhibin $\alpha$ mRNA was detected in all adrenocortical tissues. Virilizing adenomas possessed a 10-fold higher median inhibin $\alpha$ mRNA expression than did normal adrenals. Bilaterally and nodularly hyperplastic adrenals and other than virilizing adrenocortical tumours had their median inhibin $\alpha$ mRNA levels close to those of normal adrenals. Immunohistochemically, inhibin $\alpha$ subunit was detectable in all normal and hyperplastic adrenals, as well as in $73 \%$ of the adrenocortical tumours. However, the percentage of inhibin $\alpha$-positive cells varied greatly in
\end{abstract}

different tumour types. The median percentage of positive cells was 10 in non-functional and Conn's adenomas, 30 in Cushing's adenomas and 75 in virilizing adenomas. In malignant adrenocortical tumours the median percentage of inhibin $\alpha$-immunopositive cells was 20 in nonfunctional carcinomas, 30 in Conn's carcinomas, 65 in Cushing's carcinomas and 75 in virilizing carcinomas. All phaeochromocytomas were negative for inhibin $\alpha$ subunit both at the mRNA level and immunohistochemically.

Our data show that inhibin $\alpha$ subunit is highly expressed in both normal and neoplastic androgenproducing adrenocortical cells, with less expression in cortisol-producing and hardly any in aldosteroneproducing cells. This suggests a specific role for inhibins in the regulation of adrenal androgen production. We did not find any significant difference in inhibin $\alpha$ expression between benign and malignant adrenocortical tumours. Thus inhibin $\alpha$ gene does not seem to have a tumour suppressor role in human adrenal cortex.

Journal of Endocrinology (2000) 165, 223-229

\section{Introduction}

Inhibins are heterodimeric glycoproteins whose main endocrine function is supposed to be the regulation of pituitary follicle-stimulating hormone secretion. They consist of an $\alpha$ subunit linked to either a $\beta$ A subunit (inhibin A) or a $\beta B$ subunit (inhibin B) (Ying 1988). The inhibin $\alpha$ gene is located on human chromosome 2q (Barton et al. 1989). Steroid-producing organs, pituitary gland, placenta and the central nervous system are the main sites of inhibin $\alpha$ subunit gene expression (Meunier et al. 1988, Voutilainen 1995). In humans, inhibin $\alpha$ subunit gene is expressed in both foetal and adult adrenal cortex (Voutilainen et al. 1991, Spencer et al. 1992), and the inner zones, particularly the zona reticularis, have the strongest immunoreactivity with anti-inhibin $\alpha$ antibody (Chivite et al. 1998, McCluggage et al. 1998). The role of adrenal inhibins is not fully understood. Adrenocorticotrophic hormone (ACTH) has been shown to upregulate the expression of adrenal inhibins in vitro (Crawford et al. 1987, Voutilainen et al. 1991). A negative autoregulation of inhibin $\alpha$ subunit expression was suggested in a transgenic mouse study, where gonadal inhibins were shown to downregulate the expression of the inhibin $\alpha$ subunit gene in the adrenal gland (Kananen et al. 1996). Although gonads are the main source of circulating inhibins, adrenal venous blood has a higher concentration of inhibins than peripheral blood suggesting some contribution of adrenals as well (Nishi et al. 1995). 
Assessment of the growth potential of adrenocortical tumours can be complicated. Microscopic criteria of malignancy consider nuclear grade, mitotic rate, existence of atypical mitoses, diffuse architecture, necrosis and capsular or vascular invasion and absence of clear cells (Weiss 1984, Weiss et al. 1989). Flow cytometry has not offered diagnostic help in the evaluation of the malignant nature of the tumour (Cibas et al. 1990, Padberg et al. 1991, Medeiros \& Weiss 1992). Proliferation marker Ki-67 and tumour suppressor gene p53 have been found helpful in distinguishing between adrenocortical adenomas and carcinomas (McNicol et al. 1997, Nakazumi et al. 1998). Abrogation of the MHC class II expression from adrenocortical tumours has been suggested to be a sign of the malignant nature of the tumour (Marx et al. 1996). Very frequent deletions in $11 \mathrm{q} 13$ and in $2 \mathrm{p} 16$ were revealed in carcinomas, when genotyping a number of adrenocortical tumours (Kjellman et al. 1999). Inhibins have been suggested to have a tumour suppressor role for the adrenal gland, since gonadectomized inhibin-deficient mice develop adrenocortical tumours (Matzuk et al. 1992). Recently two papers reported immunoreactivity against inhibin $\alpha$ in adrenocortical tumours (Chivite et al. 1998, McCluggage et al. 1998). Further studies discovered a considerable number of adrenocortical tumours exhibiting no immunostaining for inhibin a (Pelkey et al. 1998, Renshaw \& Granter 1998).

To shed more light on the role of inhibins in human adrenal pathophysiology we studied the expression in adrenal tumours of inhibin $\alpha$ subunit gene by Northern blots, and of peptide by immunohistochemistry. The analysis of inhibin $\alpha$ expression in a large series of hormonally active and inactive adrenocortical neoplasms allows us to estimate the correlation of inhibin expression with adrenal steroidogenesis. The comparison of inhibin $\alpha$ expression in benign and malignant adrenocortical samples should reveal if inhibin $\alpha$ could have a tumour suppressor role in human adrenals.

\section{Materials and Methods}

Tissues

Tissue materials were obtained during operations performed at the Department of Surgery, Helsinki University Central Hospital. The tissue specimens were dissected and visible medullar parts were removed from normal and hyperplastic adrenals within $0.5 \mathrm{~h}$, if used for RNA analysis. Normal adrenal glands were obtained from ten patients who underwent nephrectomy for kidney tumours. Pathological adrenal tissues included 10 diffuse and 15 nodular adrenocortical hyperplasias, 15 nonfunctional adrenocortical adenomas, 23 Conn's adenomas, 21 Cushing's adenomas, 6 virilizing adenomas, 12 nonfunctional adrenocortical carcinomas, 4 Conn's carcinomas, 10 Cushing's carcinomas, 4 virilizing carcinomas and 20 phaeochromocytomas. All cases were re-reviewed histologically. Malignancy of the adrenocortical tumours was assessed according to the criteria of Weiss (1984).

\section{Immunohistochemistry}

Sections were cut from formalin-fixed paraffin-embedded blocks. They were deparaffinized in xylene and rehydrated in a series of graded alcohols. The sections were pretreated in a microwave oven in $10 \mathrm{mmol} / \mathrm{l}$ citrate buffer, $\mathrm{pH} 6 \cdot 0$, at $600 \mathrm{~W}$ for $20 \mathrm{~min}$. Endogenous peroxidase activity was blocked in $0.5 \% \mathrm{H}_{2} \mathrm{O}_{2}$ for $30 \mathrm{~min}$. Sections were incubated overnight with the primary antibody for inhibin $\alpha$ (MCA9515; Serotec Ltd, Oxford, UK) at 1:50 dilution. The detection was performed using a Vecastain ABC kit (Vector Laboratories, Burlingame, CA, USA) according to the manufacturer's instructions. The sections were lightly counterstained with haematoxylin. To exclude the effect of possible endogenous biotin on immunohistochemical staining, biotin blocking (AvidinBiotin Blocking Kit; Vector Laboratories) was performed in at least one sample of each diagnostic group prior to the addition of the primary antibody. Immunoreactivity of inhibin $\alpha$ was assessed separately by two trained pathologists (J A and K S). Twenty representative highpower fields were chosen from one slide per tumour, with a minimum of 1000 cells to be counted per tumour. The percentage of positively staining tumour cells was rounded up to the nearest $10 \%$.

\section{$R N A$ analysis}

Total RNA was isolated from the frozen tissues by ultracentrifugation through a caesium chloride cushion (Chirgwin et al. 1979). Northern blotting and hybridizations were performed as previously described (Liu et al. 1995). The relative intensities of autoradiographic signals were quantified by densitometric scanning. All data shown are normalized to the respective 28S RNA values.

\section{Probes}

The probes for human inhibin $\alpha$ subunit mRNA were two synthetic antisense 27-mer oligonucleotides. The sequence of the first oligonucleotide was $5^{\prime}$-CTC CGG AGG CCT CTG CAG CAG GCG CAG-3' corresponding to the nucleotides 693-719, and that of the second was 5'-CCA GCC CAG CTC CTG GAA GGA GAT GTT-3', corresponding to the nucleotides 759-785 of the human inhibin $\alpha$ mRNA (Mason et al. 1986). Two separate ${ }^{32} \mathrm{P}$-labelled oligonucleotides were used simultaneously to increase the sensitivity in the detection of inhibin $\alpha$ mRNA expression. Mouse ribosomal 28S RNA cDNA probe (Arnheim 1979) was used as an RNA loading control. 

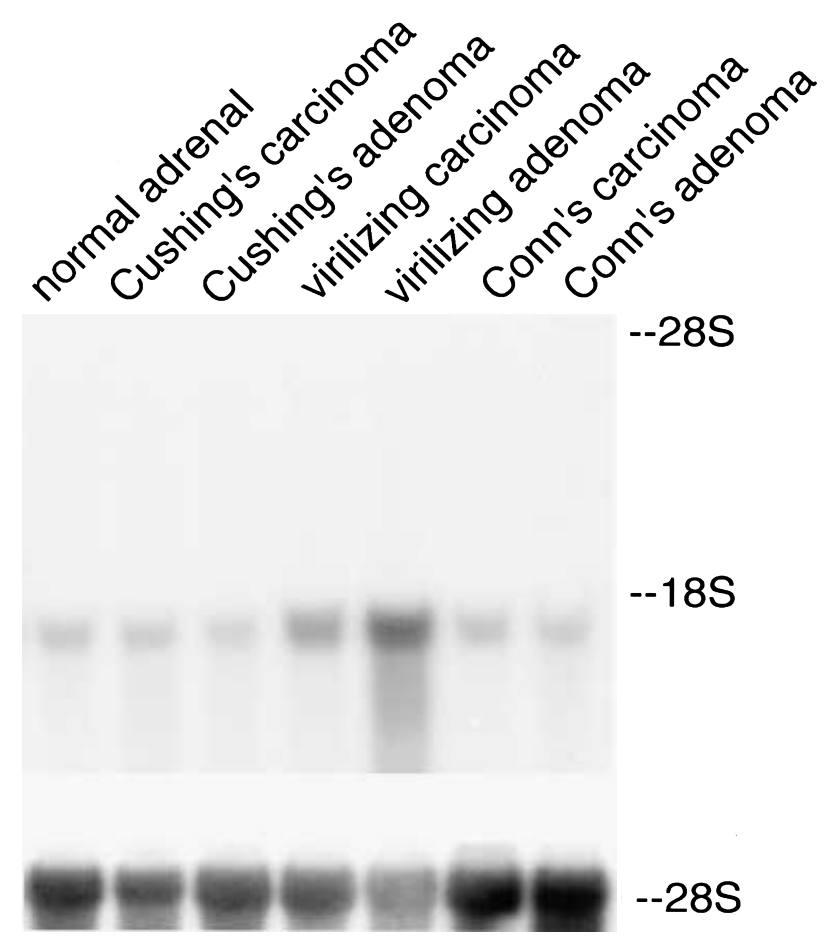

Figure 1 Expression of inhibin $\alpha$ subunit mRNA in normal adrenal gland and adrenal tumours in vivo. Total RNA was extracted from the frozen tissues indicated in the figure. The Northern blot was prepared with $20 \mu \mathrm{g}$ RNA for each lane, and the RNA was transferred onto a nylon membrane. The filter was then sequentially hybridized with the inhibin $\alpha$ subunit (upper panel) and $28 \mathrm{~S}$ ribosomal RNA (lower panel) probes. The migration of $28 \mathrm{~S}$ and $18 \mathrm{~S}$ ribosomal RNAs is indicated.

\section{Statistics}

Differences in the mRNA levels and in the numbers of the immunohistochemically positive cells were assessed by the Mann-Whitney test. The level of significance was chosen as $P<0 \cdot 05$.

\section{Results}

\section{Normal and hyperplastic adrenal glands}

Inhibin $\alpha$ subunit mRNA was detected as a $1.6 \mathrm{~kb}$ species in all normal adrenal samples (Fig. 1). In diffuse and nodular hyperplasias the median $\alpha$ subunit mRNA levels were about 2- to 3-fold as high as in normal adrenals (Table 1). Immunohistochemically, normal adrenal cortex possessed strong immunoreactivity for inhibin $\alpha$ subunit in the zona reticularis. Weaker reactivity was seen in the zona fasciculata, whereas the zona glomerulosa was negative. Adrenal medullar cells were also negative (Fig. 2). The staining pattern seen in diffusely hyperplastic adrenals was similar to that in normal adrenals, although the fasciculata cells were more intensely stained than in normal adrenals. Nodularly hyperplastic adrenals had a different staining pattern, as no zonal architecture is present; $10-30 \%$ of the adrenocortical cells were positive for inhibin $\alpha$ in these adrenals.

\section{Adrenocortical adenomas}

All adrenocortical adenomas expressed inhibin $\alpha$ mRNA and $71 \%$ of them were positive for inhibin $\alpha$ subunit immunohistochemically. In non-functional, Conn's or Cushing's adenomas, median inhibin $\alpha$ mRNA levels were close to those detected in normal adrenals, whereas virilizing adenomas possessed 10-fold as high median inhibin $\alpha$ mRNA levels as the normal adrenals (Table 1, Fig. 1). Immunohistochemically inhibin $\alpha$ subunit expression reflected the hormonal secretion of the tumour. Seven of 15 non-functional adenomas, 8 of 23 Conn's adenomas and 4 of 21 Cushing's adenomas were completely negative for inhibin $\alpha$ subunit, but all 6 virilizing adenomas were strongly positive. The median percentage of inhibin $\alpha$-positive cells was 10 in non-functional and Conn's adenomas, 30 in Cushing's adenomas and 75 in virilizing adenomas (Table 1, Figs 2 and 3)

\section{Adrenocortical carcinomas}

Inhibin $\alpha$ mRNA was detected in all adrenocortical carcinomas regardless of the functional status of the tumour. Virilizing carcinomas $(n=2)$ had about 2-fold inhibin $\alpha$ mRNA levels compared with the other carcinomas and normal adrenals (Table 1, Fig. 1). Immunohistochemically, $76 \%$ of the carcinomas stained positively for inhibin $\alpha$. The median percentage of inhibin $\alpha$-positive cells was 20 in non-functional carcinomas $(n=12), 30$ in Conn's carcinomas $(n=4), 65$ in Cushing's carcinomas $(n=10)$ and 75 in virilizing carcinomas $(n=4)$ (Table 1, Figs 2 and 3).

\section{Phaeochromocytomas}

All phaeochromocytomas $(n=20)$ were negative for inhibin $\alpha$ immunohistochemically. Northern blot analysis of inhibin $\alpha$ subunit was negative in all phaeochromocytoma samples $(n=6)$ as well (Table 1, Fig. 2).

\section{Discussion}

Both inhibin $\alpha$ and $\beta$ subunit mRNA species and peptides can be detected in adrenal cortex, but not in the medulla (Meunier et al. 1988, Voutilainen et al. 1991, Spencer et al. 1992, McCluggage et al. 1998). The first reports suggested all adrenocortical tumours to be inhibin $\alpha$ positive (Chivite et al. 1998, McCluggage et al. 1998). Later reports, however, showed equal amounts of 
Table 1 Expression of inhibin $\alpha$ subunit in adrenal tissues. Inhibin $\alpha$ mRNA - the mRNA values of inhibin $\alpha$ subunit were calculated from scanned autoradiographic signals of Northern blots, as described in Materials and Methods. The filters were sequentially hybridized with inhibin $\alpha$ and $28 \mathrm{~S}$ ribosomal RNA probes. The values for the inhibin $\alpha$ mRNA represent the $1.6 \mathrm{~kb}$ transcript. All inhibin $\alpha$ signals were normalized with the respective $28 \mathrm{~S}$ ribosomal RNA values. Medians and ranges are shown. The means of the RNA values from normal adrenals were adjusted to 100. Inhibin $\alpha$ peptide - the percentage of positively staining cells in immunohistochemistry performed with the inhibin $\alpha$ antibody was calculated from one slide per tumour, as described in Materials and Methods. Medians and ranges in each group are shown

\begin{tabular}{|c|c|c|c|c|}
\hline & \multicolumn{2}{|c|}{ Inhibin $\alpha$ mRNA } & \multicolumn{2}{|c|}{ Inhibin $\alpha$ peptide } \\
\hline & $n$ & Value & $n$ & Per cent \\
\hline Normal adrenal & 5 & $100(73-127)$ & 10 & See text \\
\hline $\begin{array}{l}\text { Hyperplasia } \\
\text { Diffuse } \\
\text { Nodular }\end{array}$ & $\begin{array}{l}8 \\
6\end{array}$ & $\begin{array}{l}200(46-828) \\
328(19-493)\end{array}$ & $\begin{array}{l}10 \\
15\end{array}$ & $\begin{array}{l}\text { See text } \\
\text { See text }\end{array}$ \\
\hline $\begin{array}{l}\text { Adrenocortical adenom } \\
\text { Non-functional } \\
\text { Conn's } \\
\text { Cushing's } \\
\text { Virilizing }\end{array}$ & $\begin{array}{l}5 \\
7 \\
9 \\
3\end{array}$ & $\begin{aligned} 52 & (25-140) \\
71 & (6-164) \\
65 & (15-315) \\
1040 & (447-2804)^{*}\end{aligned}$ & $\begin{array}{r}15 \\
23 \\
21 \\
6\end{array}$ & $\begin{array}{l}10(0-10) \\
10(0-40) \\
30(0-80) \\
75(60-100)\end{array}$ \\
\hline $\begin{array}{l}\text { Adrenocortical carcinor } \\
\text { Non-functional } \\
\text { Conn's } \\
\text { Cushing's } \\
\text { Virilizing }\end{array}$ & $\begin{array}{l}2 \\
1 \\
3 \\
2\end{array}$ & $\begin{array}{l}81(70-91) \\
98 \\
107(15-212) \\
221(198-244)\end{array}$ & $\begin{array}{r}12 \\
4 \\
10 \\
4\end{array}$ & $\begin{array}{l}20(0-90) \\
30(10-40) \\
65(0-90) \\
75(50-80)\end{array}$ \\
\hline Phaeochromocytomas & 6 & $0^{*}$ & 20 & 0 \\
\hline
\end{tabular}

${ }^{*} P<0 \cdot 05$, compared with normal adrenals.

immunonegative and immunopositive adrenocortical tumours (Renshaw \& Granter 1998). In our large series of tumours, $27 \%$ of the adrenocortical neoplasms were immunohistochemically negative for inhibin $\alpha$, confirming that negative inhibin $\alpha$ immunohistochemistry does not exclude the possibility of an adrenocortical tumour origin.

Many questions need to be answered concerning the role of locally produced inhibins in the growth and steroidogenesis of the adrenal gland. Very recently, Munro et al. (1999) suggested that loss of inhibin $\alpha$ immunopositivity in some adrenocortical carcinomas is an indicator of tumour progression. We did not find that inhibin $\alpha$ expression reflects the malignant potential of the tumour, as $29 \%$ of the adenomas and $23 \%$ of the carcinomas were negative for inhibin $\alpha$. Although studies with inhibindeficient mice suggested a tumour suppressor role of inhibin $\alpha$ in the adrenal gland (Matzuk et al. 1992) a very recent report demonstrated that a loss of genetic material from $2 \mathrm{p} 16$ was strongly associated with a malignant phenotype of adrenocortical tumours (Kjellman et al. 1999). This locus is different from that of $\alpha$ inhibin (Barton et al. 1989).

What is the function of adrenal inhibins? Although in early studies zona glomerulosa was suggested to be immunohistochemically positive for inhibin $\alpha$ (Spencer et al.
1992), most recent studies have suggested an inner zonespecific staining pattern (McCluggage et al. 1998). We also showed negative inhibin $\alpha$ immunostaining in the zona glomerulosa, weak staining in the zona fasciculata, and very strong staining in the zona reticularis. The slightly higher (though not significantly) inhibin $\alpha$ subunit gene expression detected in hyperplastic compared with normal adrenals could be explained by increased ACTH action on inhibin $\alpha$ subunit gene expression (Voutilainen et al. 1991) in hyperplastic adrenals. Alternatively, but less likely, this difference could be caused by a higher cortical to medullary tissue ratio in hyperplastic than in normal adrenals. The first alternative is supported by the impression that the fasciculata cells were more intensely stained in the diffusely hyperplastic than in normal adrenals.

Kananen et al. (1996) suggested that adrenal inhibins have a functional role in the inner zones of the adrenal cortex. Histopathological analysis of adrenocortical tumours in mice transgenic for the mouse inhibin $\alpha$ subunit promoter/simian virus $40 \mathrm{~T}$-antigen fusion gene indicated an inner layer origin of tumorigenesis. However, in our study it was not only the androgen-producing adrenocortical cells that were expressing inhibin $\alpha$. Inhibin $\alpha$ expression in adrenocortical tumours appears to be associated with the hormonal activity of the tumours. All our virilizing tumours were strongly positive for inhibin $\alpha$ both 

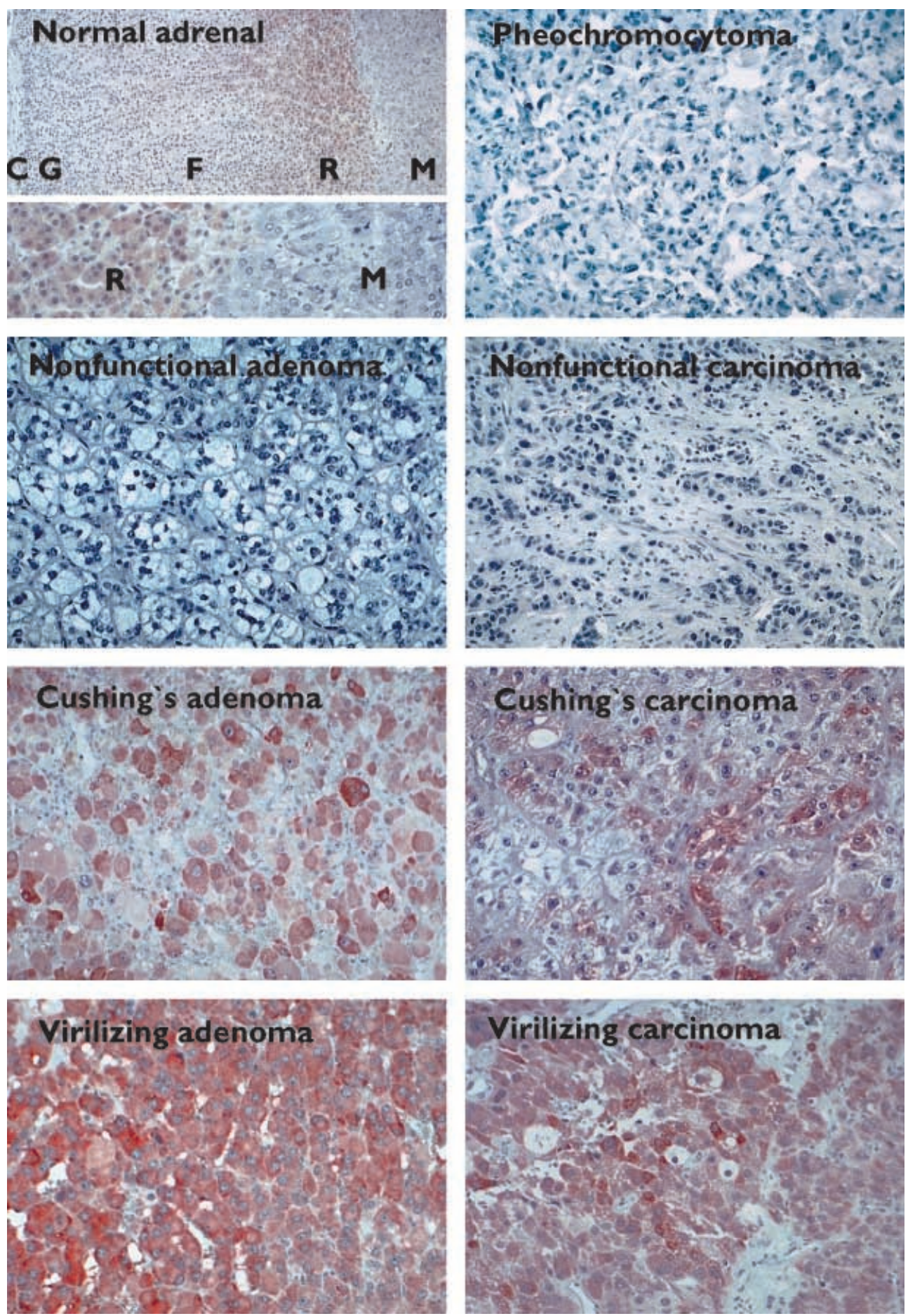

Figure 2 Expression of inhibin $\alpha$ subunit in normal adrenal gland and adrenal tumours. Immunohistochemical staining with inhibin $\alpha$ antibody was performed as described in Materials and Methods. $\mathrm{C}=$ capsule, $\mathrm{G}=$ zona glomerulosa, $\mathrm{F}=$ zona fasciculata, $\mathrm{R}=$ zona reticularis and $\mathrm{M}=$ medulla. Inset below normal adrenal illustrates higher magnification of zona reticularis and medulla. 


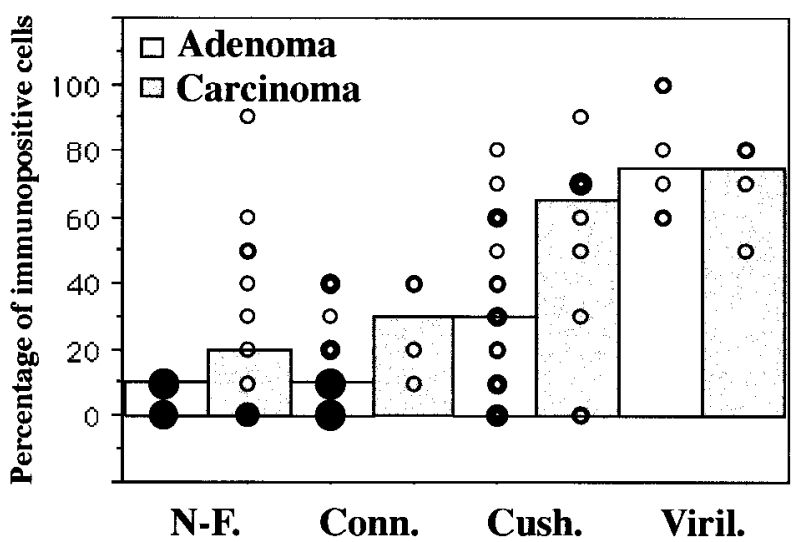

Figure 3 Expression of inhibin $\alpha$ subunit peptides in adrenocortical tumours. Immunohistochemical staining with inhibin $\alpha$ antibody was performed as described in Materials and Methods. The percentage of positively staining cells was counted from one slide per tumour. The scattergram demonstrates the percentage of positively staining tumour cells in each case. The thickness of the ring stands for the number of cases $(n=1-8)$. The median bars are shown. N-F. =non-functional adenomas $(n=15)$ and carcinoma $(n=12)$, Conn. $=$ Conn's adenomas $(n=23)$ and carcinoma $(n=4)$ Cush. $=$ Cushing's adenomas $(n=21)$ and carcinoma $(n=10)$, and Viril. $=$ virilizing adenomas $(n=6)$ and carcinoma $(n=4)$.

at the mRNA level and immunohistochemically. Most of the Cushing's tumours showed fairly strong immunostaining, although the mRNA expression was basically at the same level as in normal adrenals. Pelkey et al. (1998) also presented strong immunohistochemical staining of inhibin $\alpha$ in Cushing's and virilizing adrenocortical tumours. Very high expression of inhibin $\alpha$ in zona reticularis and in virilizing tumours supports a role of inhibin $\alpha$ in androgen production.

In summary, we observed a strong inhibin $\alpha$ expression in the zona reticularis, and a weak expression in the zona fasciculata, whereas the zona glomerulosa and adrenal medulla were negative. Inhibin $\alpha$ expression was about equal in adrenocortical adenomas and carcinomas. Virilizing tumours were strongly positive for inhibin $\alpha$ both at the mRNA level and immunohistochemically. Most glucocorticoid-producing tumours were moderately positive immunohistochemically, whereas non-functional and aldosterone-producing tumours were either negative or only weakly positive. No inhibin $\alpha$ expression was detected in any of the phaeochromocytomas. Our data suggest a steroidogenesis-related expression of inhibin $\alpha$ in normal adrenal gland and its tumours. Inhibin $\alpha$ expression does not differentiate malignant adrenocortical tumours from benign.

\section{Acknowledgements}

Ms Eija Heiliö and Ms Merja Haukka are thanked for their technical assistance. Kristina von Boguslawski is thanked for her advice on immunohistochemistry and $\mathrm{Mr}$ Antti Huittinen for his help with the illustrations. This work was supported by the Helsinki University Central Hospital Research Contract No. TYH 9107 and the Kuopio University Hospital Research Contract No. 5107 (to R V).

\section{References}

Arnheim N 1979 Characterization of mouse ribosomal gene fragments purified by molecular cloning. Gene 7 83-96.

Barton DE, Yang-Feng, TL, Mason AJ, Seeburg PH \& Francke U 1989 Mapping of genes for inhibin subunits alpha, beta A, and beta $\mathrm{B}$ on human and mouse chromosomes and studies of jsd mice. Genomics 5 91-99.

Chirgwin JM, Przybyla AE, MacDonald RJ \& Rutter WJ 1979 Isolation of biologically active ribonucleic acid from sources enriched in ribonuclease. Biochemistry 18 5294-5299.

Chivite A, Matias-Guiu X, Pons C, Algaba F \& Prat J 1998 Inhibin A expression in adrenal neoplasms. Applied Immunohistochemistry 6 $42-49$.

Cibas ES, Medeiros LJ, Weinberg DS, Gelb AB \& Weiss LM 1990 Cellular DNA profiles of benign and malignant adrenocortical tumors. American Journal of Surgical Pathology 14 948-955.

Crawford RJ, Hammond VE, Evans BA, Coghlan JP, Haralambidis J, Hudson B, Pennschow JD, Richards RI \& Tregear GW 1987 $\alpha$-Inhibin gene expression occurs in the ovine adrenal cortex, and is regulated by adrenocorticotropin. Molecular Endocrinology 1 699-706.

Kananen K, Markkula M, Mikola M, Rainio E-M, McNeilly A \& Huhtaniemi I 1996 Gonadectomy permits adrenocortical tumorigenesis in mice transgenic for the mouse inhibin $\alpha$-subunit promoter/simian virus $40 \mathrm{~T}$-antigen fusion gene: evidence for negative autoregulation of the inhibin $\alpha$-subunit gene. Molecular Endocrinology 10 1667-1677.

Kjellman M, Roshani L, Teh BT, Kallioniemi O-P, Höög A, Gray S, Farnebo L-O, Holst M, Bäckdahl M \& Larsson C 1999 Genotyping of adrenocortical tumors: very frequent deletions of the MEN1 locus in 11q13 and of a 1-centimorgan region in 2p16. Journal of Clinical Endocrinology and Metabolism 84 730-735.

Liu J, Voutilainen R, Kahri AI \& Heikkilä P 1995 Expression of the c-myc gene in human adrenals: regulation by adrenocorticotropin in primary cultures. Journal of Endocrinology 148 523-529.

Marx C, Wolkersdörfer GW, Brown JW, Scherbaum WA \& Bornstein SR 1996 MHC class II expression - a tool to assess malignancy in adrenocortical tumours. Journal of Clinical Endocrinology and Metabolism 81 4488-4491.

Mason AJ, Niall HD \& Seeburg PH 1986 Structure of two human ovarian inhibins. Biochemical and Biophysical Research Communications 135 957-964.

Matzuk MM, Finegold MJ, Su J-GJ, Hsueh AJW \& Bradley A 1992 $\alpha$-Inhibin is a tumour-suppressor gene with gonadal specificity in mice. Nature 360 313-319.

McCluggage WG, Burton J, Maxwell P \& Sloan JM 1998 Immunohistochemical staining of normal, hyperplastic, and neoplastic adrenal cortex with a monoclonal antibody against $\alpha$ inhibin. Journal of Clinical Pathology 51 114-116.

McNicol AM, Nolan CE, Struthers AJ, Farquharson MA, Hermans J \& Haak HR 1997 Expression of p53 in adrenocortical tumours: clinicopathological correlations. Journal of Pathology 181 146-152.

Medeiros LJ \& Weiss LM 1992 New developments in the pathologic diagnosis of adrenal cortical neoplasms. A review. American Journal of Clinical Pathology 97 73-83.

Meunier H, Rivier C, Evans RM \& Vale W 1988 Gonadal and extragonadal expression of inhibn $\alpha, \beta \mathrm{A}$ and $\beta \mathrm{B}$ subunits in various tissues predicts diverse functions. Proceedings of the National Academy of Sciences of the USA 85 247-251. 
Munro LMA, Kennedy A \& McNicol AM 1999 The expression of inhibin/activin subunits in the human adrenal cortex and its tumours. Journal of Endocrinology 161 341-347.

Nakazumi H, Sasano H, Iino K, Ohashi Y \& Orikasa S 1998 Expression of cell cycle inhibitor p27 and Ki-67 in human adrenocortical neoplasms. Modern Pathology 11 1165-1170.

Nishi Y, Haji M, Takayanagi R, Yanase T, Ikuyama S \& Nawata H 1995 in vivo and in vitro evidence for the production of inhibin-like immunoreactivity in human adrenocortical adenomas and normal adrenal glands: relatively high secretion from adenomas manifesting Cushing's syndrome. European Journal of Endocrinology 132 292-299.

Padberg B-C, Lauritzen I, Achilles E, Holl K, Bressel M, Klöppel G, Dralle H \& Schröder S 1991 DNA cytophotometry in adrenocortical tumours: a clinicomorphological study of 66 cases. Virchows Archiv 419 167-170.

Pelkey TJ, Frierson HF, Mills SE \& Stoler MH 1998 The alpha subunit of inhibin in adrenal cortical neoplasia. Modern Pathology 11 516-524.

Renshaw AA \& Granter SR 1998 A comparison of A103 and inhibin reactivity in adrenal cortical tumors: distinction from hepatocellular carcinoma and renal tumors. Modern Pathology 11 1160-1164.

Spencer SJ, Rabinovici J, Mesiano S, Goldsmith PC \& Jaffe RB 1992 Activin and inhibin in the human adrenal gland. Regulation and differential effects in fetal and adult cells. Journal of Clinical Investigation 90 142-149.

Voutilainen R 1995 What is the function of adrenal inhibins? European Journal of Endocrinology 132 290-291.

Voutilainen R, Erämaa M \& Ritvos O 1991 Hormonally regulated inhibin gene expression in human fetal and adult adrenals. Journal of Clinical Endocrinology and Metabolism 73 1026-1030.

Weiss LM 1984 Comparative histologic study of 43 metastasizing and nonmetastasizing adrenocortical tumors. American Journal of Surgical Pathology 8 163-169.

Weiss LM, Medeiros LJ \& Vickery AL 1989 Pathologic features of prognostic significance in adrenocortical carcinoma. American Journal of Surgical Pathology 13 202-206.

Ying S-Y 1988 Inhibins, activins, and follistatins: gonadal proteins modulating the secretion of follicle-stimulating hormone. Endocrine Reviews 9 267-293.

Received 2 August 1999

Revised manuscript received 27 October 1999 Accepted 8 December 1999 